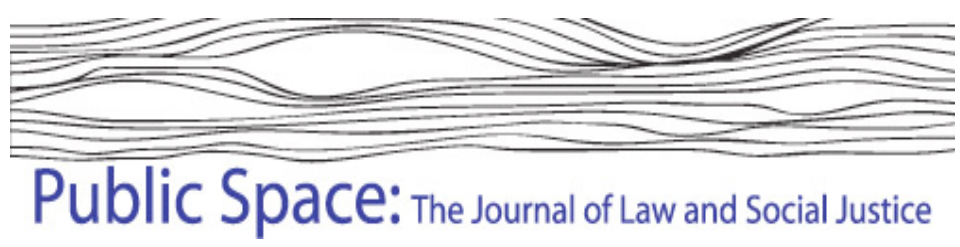

\title{
SETTLING WITH INDIGENOUS PEOPLE: MODERN TREATY AND \\ AGREEMENT-MAKING
}

\section{Edited by Marcia Langton, Odette Mazel, Lisa Palmer, Kathryn Shain and Maureen Tehan}

Publisher: Federation Press, 2006

Negotiating Indigenous land rights has become known as the new third way. It is the alternative to native title claims and claims under land rights legislation. Negotiation of land and other customary rights is a source of empowerment in a contemporary political climate that is otherwise paternalistic. It allows Indigenous people to be involved in setting the terms of land claims in terms of compensation, land access, native title rights, conservation and even governance rights. Already, over 3000 voluntary negotiations have led to settled outcomes with governments, mining companies and other stakeholders. ${ }^{1}$

Settling with Indigenous People traces many of these agreements and in doing so engages Indigenous perspectives on the process and outcomes. The book is a collection of case studies that reveal how modern agreements can provide avenues for Indigenous people to resolve outstanding historical disputes and conflicts arising from new developments. While mainly focused on Australia, there are also some valuable comparative notes on the Canadian experience.

The premise of this book is that litigation and statutory approaches are not exhaustive avenues for Indigenous outcomes. In fact, far greater results can be achieved by dispensing with these formal,

\footnotetext{
${ }^{1}$ Commonwealth Budget Paper, Indigenous Affairs 2002-2003, 14 May 2002.
} 


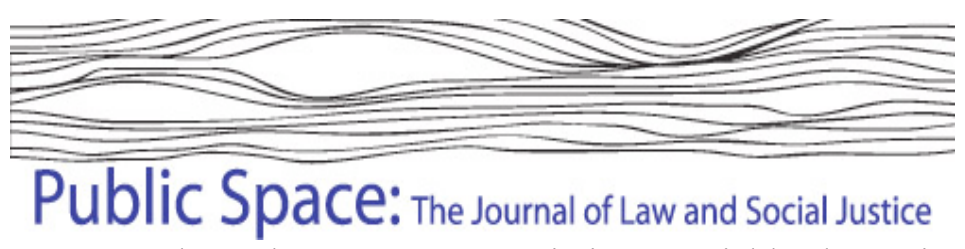

timely and costly processes. The authors present negotiations as viable alternatives for addressing exclusion and disadvantage.

Nonetheless, negotiations (like litigated outcomes) can be a long process, especially where they involve a consent native title determination. In some instances they take as long as ten years to resolve. Before native title negotiation begins, governments have to provide a licence, which can be a highly bureaucratic process.

While Settling with Indigenous People highlights many of the positive results, it tends to overshadow the structural limitations or explain why Indigenous people have to turn to negotiation. In other words, it does not elucidate the barriers in the formal system and the failure of courts and legislatures to confer sovereignty and land rights in a meaningful way for many Indigenous people.

Indigenous people, therefore, resort to negotiation because the law does not otherwise recognise their laws. The consequence is that negotiations are far from a 'level- playing field'. Governments and commercial entities are far better resourced and skilled to reach an outcome that is amenable to their needs.

But for what it sets out to do - to provide insights into the negotiating process and reveal the capacity of Indigenous people to reach workable outcomes - it does well. It is a valuable contribution to Indigenous legal scholarship, which can tend to focus on the formal avenues at the expense of informal strategies for just outcomes. 